\title{
BIOLOGICAL ACTIVITY OF SOME STEAM DISTILLATES FROM LEAVES OF TEN SPECIES OF RUTACEOUS PLANTS
}

\author{
B. M. R. BANDARA, C. M. HEWAGE, D. H. L. W. JAYAMANNE, \\ V. KARUNARATNE \\ Department of Chemistry, University of Peradeniya, Peradeniya, Sri Lanka.
}

\section{N. K. B. ADIKARAM}

Department of Botany, University of Peradeniya, Peradeniya, Sri Lanka.

\author{
K. A. N. P. BANDARA \\ Central Agricultural Research Institute, Gannoruwa, Sri Lanka.
}

\section{R. M. PINTO}

Department of Microbiology, University of Peradeniya, Peradeniya, Sri Lanka.

\section{AND}

\section{*D. S. A. WIJESUNDARA}

Botanic Gardens, Hakgala, Sri Lanka.
(Date of receipt
10 July 1989)
(Date of acceptance
27'February 1990)

\begin{abstract}
Some steam distillates collected from leaves of ten Rutaceous plents by Simple Steam Distillation method have been investigated for antimicrobial and insecticidal activity: Murraya paniculata, Toddalia asiatica, Limonia acidissima and Glycosmis pentaphylla have shown significant antifungal activity against Cladosporium cladosporioides. High antibacterial activity was displayed by L. acidissima and M. paniculata against Staphylococcus aureus. Atalantia monopbvlla and Acronychia pedunculata caused significant mortality of the aph id, Apbis craccioora.
\end{abstract}

\section{Introduction}

Rutaceae is a large family comprising of about 150 genera. Twenty genera have been recorded in Sri Lanka of which the majority are indigenous. ${ }^{7}$ The family is best known for the citrus fruits. Several other species, for example Murraya koenigii (Karapincha or Curry leaf), are grown for their aromatic leaves used in cooking and popular medicine. Some species provide edible fruits, also reputed to have medicinal value, such as the wood apple (Limonia acidissima) and beli fruit (Aegle marmelos).

Compounds having antifungal properties have been isolated from Rutaceae, for example in L. acidissima where the unripe fruit shell, stem and root-bark contain at least four compounds, viz 2-6-dimethoxybenzoquinone, psoralen, xanthotoxin and osthenol, inhibitory to a range of fungi. 1,16 Euodia lunu-ankenda is one of the several plants in this family showing

*Present address. : Royal Botanic Gardens, Peradeniya, Sri Lanka. 
antibacterial activity. ${ }^{13}$ The insecticidal component, 'neoherculin', has been isolated from Zanthoxylum clava-hercules. ${ }^{5}$ The present study describes the antimicrobial and insecticidal properties of some steam distillates collected by Simple Steam Distillation method ${ }^{9}$ from leaves of ten species belonging to the family Rutaceae.

\section{Experimental}

\subsection{Plant Material and Separation of Steam Distillates}

Plant material was collected at Belihuloya in the Central Province of Sri Lanka and identified by comparison with specimens deposited at the National Herbarium, Peradeniya. Fresh leaves $(500 \mathrm{~g}$ ) were chopped and loosely packed in 5 litre round bottommed flasks and the flasks were kept in boxes containing saw dust. Steam was passed into the flasks continuously for about $12 \mathrm{~h}$. and the steam coming out from an outlet was allowed to pass into a separate receiving flask through a condensor unit at room temperature. The resultant aqeous solution was extracted with dichloromethane (1.5-2 litres), dried with $\mathrm{Na}_{2} \mathrm{SO}_{4}$ and the solvent was evaporated in vacuo (below $40^{\circ} \mathrm{C}$ ).

\subsection{Antifungal Activity (Cladosporium TLC-bioassay)}

Stearn distillates $(2 \mathrm{mg})$ were spotted on TLC plates (silica gel $60 \mathrm{PF}_{254-366}$, $0.50 \mathrm{~mm} \times 20 \mathrm{~cm} \times 20 \mathrm{~cm}$ ) and the plates were developed in dichloromethane : light petroleum $(2: 3)$. After air-drying the plates inside the laboratory at ambient temperature $\left(28^{\circ} \mathrm{C}\right)$ they were sprayed with a suspension of conidia of Cladosporium cladosporioides in Czapek-Dox nutrient solution. Plates were then incubated in a moist chamber at $25 \pm 2^{\circ} \mathrm{C}$ for $48 \mathrm{~h}$. Inhibition areas appeared white against a background of green mycelia. The diameters of zones in which the growth was inhibited, which were approximately circular, were measured $(\mathrm{mm})$.

\subsection{Antibacterial Activity}

Tests for antibacterial activity ${ }^{6}$ were carried out using type strains of Staphylococcus aureas (NCTC 6571). Escherichia coli (NCTC 10418) was used as the control organism in antibiotic activity testing. The essential oils (16mg each)were dissolved separately in $4 \mathrm{ml}$ aliquots of ethanol and ten fold dilutions were prepared from each with nutrient broth. A series of doubling dilutions were then dispensed in $2 \mathrm{ml}$ aliquots in tubes, with concentrations ranging from $1 / 10$ to $1 / 5120$ and inoculated with a fixed bacterial inoculum. The bacterial inoculum was $0.1 \mathrm{ml}$ of a $10^{-4}$ dilution of bacterial suspension with a density equal to that of a $2 \%$ aqueous suspension of barium sulphate. At the same time the bacterial inoculum was also dispensed into an identical set of tubes of dilutions made from ethanol alone, and a tube each of nutrient broth, these being used as controls. 
The tubes were incubated $\left(37^{\circ} \mathrm{C}\right)$ overnight and observed the next day for turbidity, the highest dilution showing no turbidity being the minimal inhibitory concentration (MIC). A loopful of medium from each of the tubes was then inoculated on nutrient agar and again incubated overnight. The minimal bactericidal concentration (MBC) was considered to be that showing no growth or less than 20 colonies on semisolid medium. In the interpretation of results, the test solutions were compared with those of alcohol dilutions.

\subsection{Insecticidal Activity}

One day old opterous female aphids (Aphis craccivora) obtained from a laboratory culture maintained on cowpea plants (Vigna unguiculata) were used in these experiments. ${ }^{14}$

Each of the steam distillates of leaves were mixed with homogenate $\left(\mathrm{LF}_{12}{ }^{\mathbf{R}}\right.$, Ciba-Geigy, Bascle) $(1: 2 \mathrm{w} / \mathrm{w})$, dissolved in analytical grade acetone and distilled water $(1: 9 \mathrm{v} / \mathrm{v})$ to obtain a $1500 \mathrm{ppm}$ emulsion.

Ten aphids were placed on the underside of a detached young cowpea leaf and placed in a glass Petri-dish $(9 \mathrm{~cm}$ diameter) lined with a moistened filter paper. When they were settled, the leaf was turned upside down and sprayed with $4.0 \mathrm{ml}$ of the 1500 ppm emulsion using the Potter's spray tower. ${ }^{11}$ Then the leaf was turned right side up and the base of the petiole was wrapped with a moistened cotton plug to retard dessication. Each Petridish was covered with a plastic lid with a circular window of fine gauze. A mixture of distilled water, acetone and the homogenate was used as the standard control.

The experiments was conducted at a mean temperature $29.5 \pm 4^{\circ} \mathrm{C}$ and humidity $80 \pm 4 \% \mathrm{RH}$. Mortality counts were recorded 24 hours after treatment. A completely randomized design (CRD) with four replicates was used.

\section{Results and Discussion}

Plant essential oils belong to different classes of organic compounds having acyclic, cyclic, aromatic and heterocyclic structural features. These constituents include terpenes (mono-, sesqui- and diterpenes), aromatic compounds such as eugenol, nitrogen and sulphur containing compounds (allyl isothiocyanates) and miscellaneous compounds including unbranched long chain hydrocarbons. 15

Most of the plants which were investigated are used in ethnomedical preparations $^{4}$ (Table 1 ). The therapeutic value of these plants is no doubt due to the presence of biologically active natural products. There are several reports on the isolation of chemical constituents from the plants that were studied: alkaloids from M. koenigii ${ }^{3}$ and $G$. pentaphylla, ${ }^{2}$ coumarins from 
L. acidissima, ${ }^{16}$ T. asiatica ${ }^{17}$ and flavones and coumarins from M. paniculata ${ }^{8}$ are some of them.

Table 1: The steam distillates of leaves of ten Rutaceous plants creened for antimicrobial and insecticidal activity.

\begin{tabular}{|c|c|c|c|c|c|}
\hline $\begin{array}{l}\text { Plant species } \\
\text { (Sinhala \& Tamil names) }\end{array}$ & Habit $^{b}$ & $\begin{array}{l}\text { Reported Medicinal } \\
\text { Uses }\end{array}$ & $\begin{array}{l}\text { Part(s) } \\
\text { Used } \\
\text { Medici- } \\
\text { nally }\end{array}$ & $\begin{array}{l}\text { Weight } \\
\text { of Plant } \\
\text { Material } \\
\text { Used(g) }\end{array}$ & $\begin{array}{l}\text { Weight } \\
\text { of Esse- } \\
\text { ntial oil } \\
\text { (g) } \\
\text { (\%yield) }\end{array}$ \\
\hline
\end{tabular}

\begin{tabular}{|c|c|c|c|c|c|}
\hline $\begin{array}{l}\text { Acronychia pedunculata (L.) } \\
\text { miq. (S:Ankenda) }\end{array}$ & ST & Sores and ulcers & Bk & 1000 & $\begin{array}{l}0.580 \\
(0.058)\end{array}$ \\
\hline $\begin{array}{l}\text { Atalantia ceylanica (Arn.) } \\
\text { Oliv.(S:Yakinaran; T:Peykurutu) }\end{array}$ & $\mathrm{Sla}_{2}-$ & $\begin{array}{l}\text { Administration of } \\
\text { pills, prevent ague }\end{array}$ & Lf & 250 & $\begin{array}{l}0.340 \\
(0.136)\end{array}$ \\
\hline $\begin{array}{l}\text { Atalantia monophylla (Roxb.) } \\
\text { DC (S:Apassu; T:Perunkuruntu) }\end{array}$ & $\mathrm{ST}$ & $\begin{array}{l}\text { Skin diseases rheuma- } \\
\text { tism and paralysis }\end{array}$ & Lf, Ft & 300 & $\begin{array}{l}0.770 \\
(0.257)\end{array}$ \\
\hline $\begin{array}{l}\text { Clausena indica (Dalz.)Oliv. } \\
\text { (S:Meegon Karapincha;T:Pannai) }\end{array}$ & ST & Not reported & - & 990 & $\begin{array}{l}4.240 \\
(0.428)\end{array}$ \\
\hline $\begin{array}{l}\text { Glycosmis pentaphylla (Retz.) } \\
\text { A.DC. (S:Dodan pana; } \\
\text { T: Kulapannai) }\end{array}$ & ST & Fever & $\mathbf{R t}$ & 800 & $\begin{array}{l}2.090 \\
(0.261)\end{array}$ \\
\hline $\begin{array}{l}\text { Limonia acidissima L. } \\
\text { (S:Diwul; } \mathrm{T}: \mathrm{Nila}-\text { vilam) }\end{array}$ & $\mathrm{T}$ & $\begin{array}{l}\text { Astringent, Sore throat, } \\
\text { dysentry and diarrhoeg }\end{array}$ & $\mathrm{Ft}, \mathrm{St}$ & 1100 & $\begin{array}{l}1.810 \\
(0.163)\end{array}$ \\
\hline $\begin{array}{l}\text { Murraya koenigii (L.) Spreng } \\
\text { (S:Karapincha; T:Kuruvepillai) }\end{array}$ & sh & $\begin{array}{l}\text { Stomachic, purgative, } \\
\text { vomiting, febrifuge }\end{array}$ & $\mathbf{R t}$, Lf & 715 & $\begin{array}{l}1.210 \\
(0.169)\end{array}$ \\
\hline $\begin{array}{l}\text { Murraya paniculata (L.) Jack. } \\
\text { (S:Ettariya) }\end{array}$ & $\sin$ & $\begin{array}{l}\text { Stomachic, rheumatic } \\
\text { fever, cough, giddiness, } \\
\text { hysteria. }\end{array}$ & $W_{p}$ & 800 & $\begin{array}{l}1.650 \\
(0.206)\end{array}$ \\
\hline $\begin{array}{l}\text { Toddalia asiatica (L.) Lamk. } \\
\text { (S:Kudumiris; T:Milkaram) }\end{array}$ & $\mathrm{Cl}$ & $\begin{array}{l}\text { Pains in the bowels, } \\
\text { rheumatic swellings, } \\
\text { fever }\end{array}$ & Lf, Rt & 225 & $\begin{array}{l}0.235 \\
(0.104)\end{array}$ \\
\hline $\begin{array}{l}\text { Zantboxylum rbetsa (Roxb.) DC. } \\
\text { (S : Katukeena; T : Rhetsamaram) }\end{array}$ & $\mathrm{T}$ & Not reported & - & 200 & $\begin{array}{l}0.080 \\
(0.040)\end{array}$ \\
\hline
\end{tabular}

a Nomenclature used follows Dassanayake and Fosberg ${ }^{1}$

b $\mathrm{Sh}$ - shrub; ST - small tree; $\mathrm{Cl}$ - climber; $\mathrm{T}$ - large tree'

c According to Chandrasena 11

d Lf - leaf; Ft - fruit; Bk - stem bark; Rt - root; Wp - whole plant 
Steam distillates of ten plants were tested for antimicrobial activity against Cladosporium cladosporioides, Staphylococcus aureus and Escherichia coli and for insecticidal activity (Table 3) against Aphis craccivora koch. (Table 2).

Table 2, Antimicrobial and insecticidal activity of the steam distillates of leaves of ten Rutaceous plants

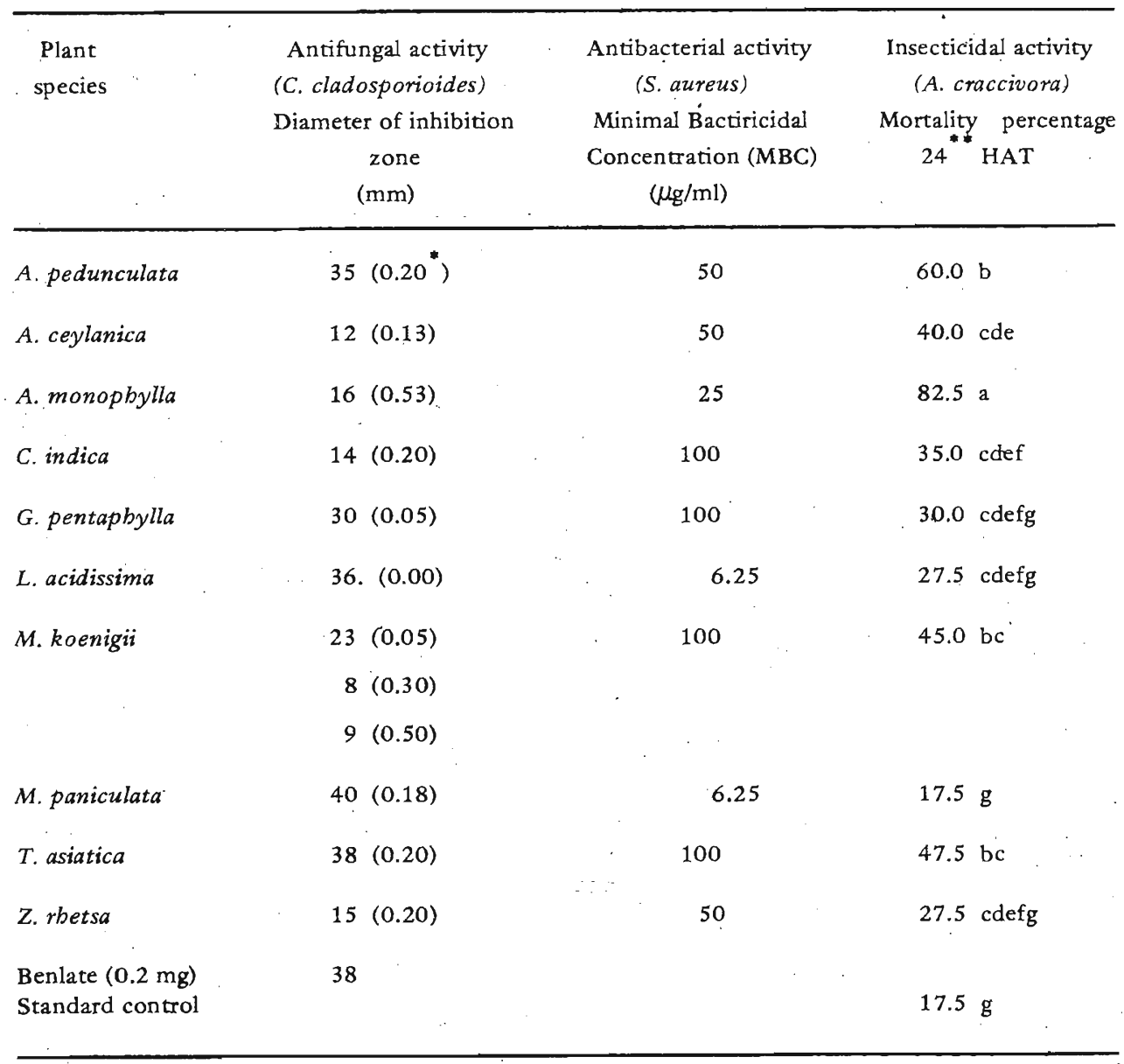

* Rf value (Dichloromethane : Light Petroleum - 2:3)

* HAT $=$ Hours After Treatment

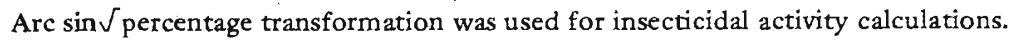

$\mathrm{P}<0.05 \mathrm{c.v}=17.8 \%$. Means followed by the same letter are not significantly different $(\mathrm{P}<0.05)$ by Duncan's multiple range test. ${ }^{12}$ 
Steam distillates of all ten plants showed antifungal activity against C. cladosporioides using the TLC-bioassay technique (Table 2). M. paniculata, T. asiatica, L. acidissima, A. pedunculata and G. pentaphylla showed high antifungal activity almost comparable with that of benlate. Interestingly, M. koenigii produced three inhibition areas, of which the highest polar constituent showed the greatest activity. The other steam distillates derived from A. monophylla, Z. rhetsa, C. indica and A. ceylanica showed comparatively low activity. There are no previous reports available on the antifungal activity of these plants other than $L$. acidissima. ${ }^{1,16}$

None of the steam distillates showed antibacterial activity against E. coli, the representative test organism of Gram negative bacteria. However, activity against $S$. aureus, the representative test organism of Gram positive bacteria, was shown by all steam distillates at different dilutions. Of the steam distillates the highest activity was shown by L. acidissima and M. paniculata (at $6 \mathrm{ppm}$ level of the crude extract).

The steam distillates from leaves of $A$. monophylla, A. pedunculata, T. asiatica, $M$. koenigii and $A$. ceylanica caused significant mortality of the aphid, A. craccivora, when compared with the untreated control (Table 2). To our knowledge this is the first report of such promising insecticidal activity in 'these plants.

This preliminary study indicates that the members of the family Rutaceae contain volatile substances having antimicrobial and insecticidal properties. Interestingly, the two plants for which there are no reported medicinal uses, $Z$. rhetsa and $C$. indica have shown only moderate or low activity compared to the other plants. L. acidissima and $M$. paniculata have shown significant antifungal and antibacterial activities while A. monophylla has shown the highest insecticidal activity. The probable role of at least some of these substances would be self-defence against invading pests. Further investigations into their biological importance and role in nature would therefore prove useful.

\section{Acknowledgements}

Financial assistance from NARESA, Sri Lanka and IFS, Sweden is gratefully acknowledged.

\section{References}

1. ADIKARAM, N.K.B., ABHAYAWARDHANE, Y., RATNAYAKE BANDARA, B.M., LESLIE GUNATILAKE, A.A. \& WIJERATNE, E.M.K. (1989) Plant Patbology 38, 258.

2. CHAKRABORTY, D.P. \& BARMAN, B.K. (1961) Trans. Bose Res. Inst. 24, 121, GoviNDACHARI, T.R., PAI, B.R. \& SUBRAMANIUN, P.S. (1966) Tetrabedron 22, 3245. 
3. CHAKRABORTY, D.P., ROY, S. \& GUHA, R. (1978) J. Indian Chem. Soc. 55(11) 1114-5; RAMA RAO, A.V., BHID, K.S. \& MUJUMDAR, R.B. (1980) Cbem. Ind. (London) 17, $697-8$.

4. CHANDRASENA, J.P.C. (1935) The Chemistry and Pharmacology of Ceylon and Indian Medicinal Plants, Colombo, $\mathrm{H}$ and $\mathrm{C}$ Press.

5. CROMBIE, L. (1955) J. Chem. Soc., $995-8$.

6. CRUICKSHANK, R., (1965) Editor, Publisher, E \& S Livingston Ltd. Edinburgh, Medical Microbiology. A Guide to Laboratory Diagnosis and Control of Infection.

7. DASSANAYAKE, M.D. \& FOSBERG, F.R. (1985) A revised handbook to the Flora of Ceylon, V, P. $406-476$.

8. DE SILVA, L.B., DE SILVA, U.L.L., MAHENDRAN, M. \& JENNINGS, R.C. (1980) Pbytochemistry 19(12), 2794. Yang, J. and Du, M. (1984) Zhiwa Xuebae, 26, $184-8$.

9. FURNISS, B.S. et al., (1978), Vogel's Testbook of Practical Organic Chemistry, 4 th Edition, ELBS and Longman Group Limited, London.

10. GOMEZ, K.A., GOMEZ, A.A., (1984) Statistical Procedures for Agricultural Research, 2nd: Edition, An International Rice Research Institute Book, John Willey \& Sons, New York, pp. $8-20$ and $207-215$.

11. HEINRICHUS, E.A., CHELliah, S., VAleNClA, S.L., ARCEO, M.B., FEbELLAR, L.T., AQUINO, G.B. \& PICKIN, S. (1981) Manual for Testing Insecticides on Rice, IRRI, Philippines p. $25-41$.

12. KLARMAN, W.L. \& STANFORD, J.B. (1968) Life Sciences, 7, 1095.

13. MANANDAR, M.D., HUSSAIN, F.A., KAPIL, R.S. \& SHOEB, A. (1985) Phytochemistry, 24(1), 199.

14. PETERSON, A. (1965), Entomological Techniques : How to Work with Insects. Entomological Reprint Specialists Los Angels, California, U.S.A.

15. PINDER, A.R. (1960) The Chemistry of the Terpene, The University Press, Northern Ireland, Belfast, P $1-4$.

16. RATNAYAKE BANDARA, B.M., GUNATILAKA, A.A.L., KITHSIRI WIJERATNE, E.M. \& ADIKARAM, N.K.B. (1988) Planta Med. 54(4) $374-5$.

17. SHARMA, P.N., ABOO, S., KAPIL, S.R., \& POPLI, S.P. (1981) Phytochemistry, 20(2), $335-6$. 